\title{
ISLAMIC CIVILISATION: AWAKENING PARAMETERS
}

\author{
Saim Kayadibi*
}

\begin{abstract}
The Muslim world's significant contribution to the development of world civilisation deserves further investigation. History's leading Muslim empires all assumed momentous responsibilities in adapting Islamic civilisation to changing times. The author argues that researching and studying the input of their intelligentsias and elites would be a necessary requirement for any Islamic 'renaissance'. Western civilisation, often presented as the only civilisation that has enabled the world to progress, ignores the contributions of all other civilisations. This article underlines the significance of Islamic civilisation by exploring the Muslims' reawakening process and humanity's need for a new world system, one that reflects Islamic civilisation's understanding and practice of ontological freedom, security, and human rights.
\end{abstract}

\section{Introduction}

The intellectual, cultural, and methodological parameters of Muslim society are shaped by Islam's fundamentally dynamic character which created and then maintained a centuries-long lively religious, political, social, and economic environment for countless peoples over the world. During these fourteen centuries Islamic civilisation, which understands itself to be the completed form of the timeless message brought by the Abrahamic line of prophets, enlightened the Muslim sphere west and east from Iberia to China and Southeast Asia, enabling it to foster the progress of other world civilisations. The Qur'an states that God created human diversity so that its various groups would come to reciprocally know one another's worldviews, lifestyles, cultures, and values (see Qur'ān 49:13). All these aspects combine to create the variety of civilisations. To mutually 'know each other' requires the existence of some type of relationship. This relationship should not be directed toward destroying the values and cultures of other civilisations, but should prompt them all to benefit from the other and experience positive progress.

In contrast to Islamic civilisation, the prevailing globalising Euro-American monolithic civilisation has in recent times threatened the foundations of other

* Saim Kayadibi is an Associate Professor of Economics in the Kulliyyah of Economics and Management Sciences at the International Islamic University Malaysia (IIUM), Kuala Lumpur. He would like to thank IAIS Malaysia Principal Research Fellow Karim D. Crow for his suggestions on various earlier versions of this article. 
traditional civilisations. Its perception of itself as an exceptional civilisational development whose ontological parameters require displacing or effacing those (non-Western) values at variance with its own is producing dissonance and conflict globally. Western civilisation pursues its own monopolistic interests by seeking to unilaterally impose its set of privileged values conveying definite technological, strategic, political and economic priorities. Nature, the natural environment which belongs to humanity as a whole, is a divine trust that must be used appropriately and not wasted or destroyed. Islamic civilisation emphasises that people should "eat and drink and be not wasteful" (Qur'ān 7:31). ${ }^{1}$ However, the current global Western civilisation encourages people to consume everything they produce, from material and organic resources to finished products, from food to cloth, through applications of technology and industry.

In order to protect our culture and values, Muslims have to revitalise and refresh our civilisational memory, our distinct sense of self-perception and awareness, and our self-confidence - for all other corollary elements follow in their wake. The emergence of genuine self-confidence rooted in proper ontological awareness of our own civilisational potential, hastens people's psychological motivation to oppose injustice, reject monopolistic exploitation, and deflect the hegemonic worldview thrust upon us through financial and military dominance. Over recent decades many Muslims are beginning to manifest an energising self-awareness and self-confidence in the face of the prevailing exceptionalist civilisation of Late Modernity. Each individual who effectively embodies an alternative worldview thereby becomes a point of light for energising communal action and for re-awakening Islamic civilisation. More attention needs to be paid to the human resource of the intellect and cultural supports moulding the parameters of our new civilisational requirements. Aware of this need, Muslim thinkers, leaders, and civic actors are trying to inject their dynamism into the existing world system.

As discussed below, such vitality is a significant indication providing hope for transferring the centre-of-gravity of an emergent cosmopolitan civilisation to the East - to Asia. This awakened vitality arising from a deepened ontological awareness will eliminate the widespread misperceptions about Islam. We mean both the wrong understandings and distortions held within the dominant Western worldview, as well as those misperceptions and shallow distortions which continue to operate among Muslims themselves regarding their genuine civilisational roots. (An example of this is the wrong perception that violence and bloodshed are legitimate paths for achieving the requirements of Muslims.) 


\section{Towards Civilisational Awakening}

The fate of a civilisation does not resemble the fate of human beings. A civilisation is born and then, according to the flow of historical events and social change, reaches maturity. Although it eventually declines and enters stasis, it may begin to reawaken when called upon to interact with new social and historical realities either arising within or imposed from without. The formation and development of civilisations are linked to historical ferment and intersections. Such historical junctions are sites of civilisational vitality and thus represent the hope of harmonising the institutionalisation of social systems which embody individual and social imagination. However, as Ahmet Davutoğlu observes, a "civilisational crisis emerges when man begins to think that his hope is victimised by the leviathan of the social mechanisms." How many times has Islam engendered successive civilisational spaces and cultural blocks? Medina served as the foundation and starting point for Islam's civilisational compass. Under the Umayyads, the seat of Islamic cultural dynamics moved to Damascus, then east to Baghdad under the Abbasids. The civilisational space of Andalusia in the West was a significant fruit of Islamic civilisation. The cultural polities erected by the Seljuks, Ottomans, and the Transoxianans in Central Asia represent further variations, as did their counterparts in Iran, South and East Asia, and Africa. The ethos of Islam generated and sustained these civilisational spaces with their own distinctive cultural components, ${ }^{3}$ and all exhibiting the spark of civil enlightenment and human dignity essential for civilisational formation.

Muslim achievement in the construction and maintenance of diverse civilisational spaces was not confined to mediating the qur'ānic vision of human dignity, but extended to many other fields. Muslims advanced and deepened the concept of politics and diplomacy at a time when Europe was sunk in chaos and political calamity. Instead of provincialism or nationalism, the Muslims grounded their societies upon multiculturalism through ensuring religious tolerance, ethnic and linguistic diversity, and the protection of minority non-Muslim communities. The polities of the Seljuks, various South Asian dynasties, and the Safavids in Iran spring to mind. The Ottoman Empire welcomed the Jews driven out of the Iberian Peninsula during the Reconquista, as it did those Christian communities fleeing persecution in Europe. This practice of diversity and inter-religious cooperation, as well as the Ottomans' pluralistic approach to rule and its multi-ethnic structure, were not exceptions; in fact, they embody Islamic civilisational norms. ${ }^{4}$ Ottoman society, for example, was based on the pluralistic millet system. Although some scholars maintain that the nation is, to a certain extent, the same as the millet, ${ }^{5}$ the European-derived nation-state system ultimately destroyed the empire's harmonious regional system by successfully presenting itself to be an alternative and inevitable world system. ${ }^{6}$ Thus, in the wake of the Enlightenment, European imperialism universalised the nation-state system, ${ }^{7}$ which prompted the multiethnic 
Ottoman Empire to decline, and promoted Islamic identity to become subsumed by ethnic-group feeling - whether Arab, Turk, Iranian, or Malay.

A new era of geopolitical and geo-cultural change is now launched in the Muslim world, which no longer is seen to consist only of Africa and Asia. Today the reality of 'Eurasia' has become apparent. In the central lands of Islam this geo-cultural reawakening is taking place from Albania to Tatarstan, from Bosnia-Herzegovina to Chechnya, from the Crimea to Tajikistan to Pakistan. They all represent a transformation of Islamic identity into a specific 'Eurasian' Muslim identity. Establishing Pakistan with an Islamic identity apart from India was yet another significant transition point in the recent history of Islam. All such new formations signify a reawakening against neo-colonialism in all of its aspects. ${ }^{8}$ Attempts at 'dialogue' based on Western-oriented understanding do not represent a genuinely mutual inter-civilisational understanding, for it is no more than a 'monologue of instruction' handed down from on high by a one-sided perspective which posits its own exceptionalism. ${ }^{9}$ Such unbalanced 'talking at' (rather than 'talking with') seeks to reinforce its own way of life and understanding as normative and universal.

\section{So-called 'Western-centric' Civilisation}

A civilisation's true face is largely determined by historical and social events, in conjunction with its internally generated prerogatives. As an individual's quality is determined by social measures, one's essence is revealed when his or her fortitude and patience are tested. This is also true of civilisations, which reveal their true essence when they face chaos and a period of transition. Peoples often fall into the seductive trap of desire to acquire material advantages in the process of obtaining freedom from foreign exploitation and recovering their innate dignity. They may suddenly lose their consciousness of ontological freedom because of the attraction of technology and its corollary materialism. This pervasive reality leads to a number of dilemmas arising out of civilisational imbalances.

We clearly see that the Western dominated global world system seeks to control other peoples by hindering them in approaching its level of technological superiority. This is done by monopolising scientific technology and controlling access to its products. A case in point is the West's double-standard regarding Iran's alleged nuclear weapons programme. The West fears that if any Islamic nation actually becomes its technological equal, then disclosure of its own exceptionalist double-standard might cause its western-centric civilisational dominance to weaken. But given its assertions of universal freedoms and human rights, why does it seek to prevent others from exploiting the fruits of technology? Clearly, their assertions mean no more than "we believe in the sovereignty of superiority" - another expression for modern slavery. No free people will ever accept this mentality, since it violates the ontological freedom 
inherent in human dignity.

The tension between Iran and the United States and its continental allies increased after Iran rejected the preliminary agreement of 1 October 2009 in Geneva. Under this agreement, Iran was to send 75 percent of its stockpiled low-enriched uranium (LEU) to Russia for conversion into fuel for humanitarian purposes and medical research. The only condition was that Russia would return about 20 percent of it which would be sent to France for conversion into fuel rods. Owing to Iran's suspicion of American intentions, based on recent historical experience, this proposal fell through. ${ }^{10}$ Then US President Obama requested Turkey to mediate. Turkey took its responsibility seriously and teamed up with Brazil. Their effort was crowned with success when on 17 May 2010 Iran agreed to swap its stockpile of enriched uranium. Presented as a chance for the United States and its allies to resolve their disagreement via diplomacy, Washington nevertheless repeatedly forced the UN to impose even more sanctions.

Strangely, the Turkish-Brazilian solution which Iran accepted was exactly what the United States and its allies had requested from Iran at first. "But as this achievement could not be attributed to the Vienna Group, it was rejected." In other words, "If I couldn't achieve it, you also can't achieve it." According to the Turkish foreign minister Davutoğlu, "This is a test for all of us whether we will solve problems through conflict or negotiation. As for Turkey and Brazil, we convinced Iran to use diplomatic means. The Tehran deal was reached thanks to flexible policies by the Iranian administration." ${ }^{\prime 1}$ Turkish prime minister Erdogan's statement is also highly significant: "This is the time to discuss whether we believe in the supremacy of law or the law of the supreme and superiors ...." ${ }^{12}$ Now is the time to end this obvious hypocrisy and to give every nation with the human and technological resources an equal opportunity to produce nuclear power for peaceful purposes.

Another predicament of the mind-set conditioning Western polities and their ruling elites is its man-centred epistemology. Considering the biological animal termed 'man' to be the absolute source for authority and value limits the true nature of the human being. Westerners assume that the ultimate truth can only be achieved through an anthropocentric epistemology which calls for separating the source of knowledge from the divine transcendent origin. ${ }^{13}$ The Western worldview posits that whatever can be justified on self-interested economic or financial grounds is legitimate, taken as an axiom supported by instrumental reason. Thus nature must be dominated so that its resources can be plundered mercilessly, for how else can the pursuit of a secular paradise on Earth where people can fulfil their material needs be realised? Another civilisational perspective was offered by the Native American Chief Seattle in his letter to the Washington authorities in $1854 .{ }^{14} \mathrm{He}$ states the true nature of the Western need to dominate as a violation of the harmonious balance sustaining all of existence.

The Islamic understanding of the wholesome human-nature relation cannot be considered as a form of possessive psychology, for the Qur'ān itself proclaims an 
inseparable link between humanity and nature and between the science of nature and religion. ${ }^{15}$ Religion plays a significant role in shaping the various social, geographical, cultural, and economic milieus wherein Islamic cultures maintained an environment designed specifically to foster its vision of harmony. One may even conclude that religion and politics, when working for a common goal, may actually cause a society to flourish and fulfil the conditions for human wellbeing and equity.

In contrast to the essential roots of Islamic civilisation, the contemporary Western globalised civilisation seeks to monopolise and control human culture. This 'hegemonistic-monopolistic' character threatens all other civilisations with which it comes into contact. In fact, it represents a major threat "to the diversity of the historical, cultural accumulation of human beings." Pitirim Sorokin summarised the work of the civilisational historian Arnold Toynbee, by remarking:

"that out of twenty six civilisations no less than sixteen are by now dead and buried including the Egyptian, the Andean, the Sinic, the Minoan, the Sumeric, the Mayan, the Indic, the Hittite, the Syriac, the Hellenic, the Babylonic, the Mexican, the Arabic, the Yucatec, the Spartan and the Ottoman. A. Toynbee concluded that the remaining ten surviving civilisations: the Christian Near East, the Islamic, the Christian Russian, the Hindu, the Far Eastern Chinese, the Japanese, the Polynesian, the Eskimo and the Nomadic, are now in their last agonies being under the threat of either annihilation or assimilation by western civilisation."16

Western exceptionalism with its presumption of civilisational universality not only monopolises the possibilities for other civilisations and cultures to follow their own path, but enforces its own globalised culture of consumption, waste, and environmental ruination which induces these new consumers to lose their own cultural roots and civilisational memory to the point of extinction. ${ }^{17}$ Civilisational amnesia within the consciousness of Muslim ontological awareness has already taken root, with Muslims orphaned from their true legacy.

\section{Toward Reawakening}

Any reawakening must fulfil certain parameters to be actual. Foremost among these parameters is to possess those significant values which create and foster a dynamic civilisation: the self-awareness of its distinctive being (ontology), a methodology of knowledge (epistemology of unitive integration), an inherent hierarchy of value (axiology), and integral institutions embedded in society (a social cosmology) - for all these are natural features of the interdependent relationship between these values and the society in question. It is evident that these values form the core parts of Islamic civilisation's dynamic character. ${ }^{18}$ Islam is a phenomenon that covers all aspects of a person's life: from various epistemic disciplines to economic strengths, architecture 
to poetry, jurisprudence to mysticism, and from algebra to social restructuring and philosophy. Each element of diversity and difference in society reflects the richness of its sought-for civilisational awakening. Moreover, such intra-diversities are a mercy strengthening the potential power to create an authentic alternative civilisational perception rooted in both individual and communal awareness.

Given all of the above, the parameters for the Muslim world's civilisational reawakening are not limited solely to periods of crisis. Although such periods have undoubtedly served as trigger factors, we argue that the Muslim world has an inherently dynamic character facilitating its self-transformation for the better ... or for the worse. Even when the external impacts and confrontations should induce or reinforce a crisis, such a crisis could result in a positive impact due to the inherent quality of human dignity and innate values which Muslims possess. In other words, the manifestation of an Islamic alternative may be provoked by the crisis and tensions in the world system's political and social agenda - born from an instinctive posture of self-defence and protective response. ${ }^{19}$

Despite all of the crises experienced, and the undeniable ethnic and national differences which separate them, Muslims have traditionally considered themselves to be one nation, one ummah or community, and one polity: the 'Abode of Islam'

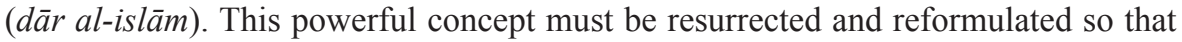
artificial man-made borders now existing in the Muslim world may become a source of mutual strength, as opposed to the present reality of enforcing division or disunity. One might envision existing Muslim nation-states and territories as small strong families strengthening the Abode of Islam's collective presence. A state's basic structure consists of small families, who make up neighbourhoods in cities, which in turn cumulatively constitute a nation. Logically, the more strong families there are, the stronger a country will be. Re-inventing the global Muslim ummah is thus a primary task.

Sustaining every individual Muslim personality are two fundamental psychological impulses:

1. to establish the most proper social atmosphere, achieved by establishing institutions to create and then maintain civilisational vitality leading to Islamic civilisational sovereignty and authenticity; and

2. to embody the Islamic belief system's theoretical ideals and values as the foundation of social dynamism, as opposed to values borrowed from the now dominant Western controlled world system.

The Muslim individual's ontological consciousness reflects his or her behavioural mode reinforcing self-confidence as a consequence of recovering healthy and dynamic self-awareness. Assuming the designated role of Allah's representative upon Earth (khalïfat Alläh) is a great responsibility for humanity, since fulfilling this ethical and existential obligation prompts human beings to reawaken their 
ontological consciousness. Humanity's responsibility is inherent in the creation of each human being, for, as the Qur'ān proclaims "We have created humanity in the best of moulds." ${ }^{20}$ Therefore everything was created for the khalïfat Alläh, who "must not serve anybody; he must not be a means. Everything must serve man and man must serve God only. This is the ultimate meaning of humanism." ${ }^{21}$ Once this is achieved, the individual is aided in striving to become a significant being serving the common harmony of creation, instead of an artificial subject guided by instinctive biological or social needs. Such Islamic self-perception can only be established if each Muslim retains this ontological consciousness. ${ }^{22}$

The reasons for a civilisation's rise and fall may be comprehended by analysing the perception of time and of history. Understanding how homo occidentalis and homo islamicus imagine time offers significant insight into explaining these two particular phenomena. The Western consciousness perceives time as a unidirectional historical flow, notably involving the idea of progress, while the Islamic awareness views history and time based on circularity and emphasises the persistence and constancy of positive values and modes of behaviour. Thus globalised Western civilisation, lacking value-legitimacy and dependent upon material and technological superiority and control of information, is not necessarily the ultimate development or exceptional form of human civilisation. Therefore, Muslims need to be meticulous and highly selective when interacting with it. This circular or spiral perspective also brings Muslims to the conviction that Islamic civilisation, which long ago lost its status of being a determinant civilisational force, can regain this status by renovating its value-parameters, rather than renouncing them and replacing them with imported western parameters. ${ }^{23}$

The Qur'ān establishes Islamic value-parameters by relating its teaching about what caused previous civilisations and societies to fall: the deterioration of social ethics, not the end of rationality or material superiority. ${ }^{24}$ It proclaims: "Therefore their Lord crushed them for their sin and razed them;",25 "[f]or we are shall bring down on the people of this township a punishment from heaven, because they have been wickedly rebellious;",26 or "so We overtook them for what they had earned [of inequity]," ${ }^{27}$ and many similar statements. It is evident that the inherent parameters of Islamic civilisation are based on value structures, deeply embedded ethical virtues, and the very nature of the human soul - which together constitute the essential energy of civilisations. When these factors are no longer dominant, decadence appears and the society eventually collapses. ${ }^{28}$

On the other hand, a civilisation's reinforcement must be renewed and developed according to the needs of the time when its core dynamics were continually refreshed. Our emergent civilisation must have its own technique, artistic and aesthetic expression, a dynamics of opinion, a scientific network to facilitate development, and preventative measures designed to confront any unexpected situation. In addition, 
it should support the state by developing and producing its indigenous military equipment and forces both to defend itself and to free Muslims from dependence upon foreign powers. ${ }^{29}$ Any civilisation that loses its fundamental dynamics of spirit and religious values, which energise it, is doomed.

Moving the civilisational axis from the West to the Muslim world and Asia is not the same as shifting it from one Muslim region to another. Shifting this axis from Damascus to Baghdad, and from Baghdad to Istanbul, from the civilisationally vivacious Andalusia to the leading Islamic cities of India and Ottoman Turkey, were all considered intra-civilisational crises. Even though the Mongols destroyed many of the Islamic world's core civilisational centres, a number of these regained their civilisational vitality because the destruction was limited to the material sphere. In other words, a civilisational crisis might be more evident within, rather than between, civilisations. ${ }^{30}$ However, this did not hold true when colonial Europe penetrated the Muslim world and enforced its civilisational ethos along with its intellectual, military, political, and economic values. In short, Europe sought to impose a counter-selfperception on the Muslim world, and to efface the indigenous ontological awareness.

As civilisation is a "continuous progress", ${ }^{31}$ the Muslim world must re-possess those aspects that have atrophied or been lost. To function once again as its own civilisational axis, it must rethink and reclaim those values which in its often violent encounters with Europe, and now America, it lost, departing from its main objectives. One major issue here is how to deal with the indigenous yet westernized elites and intellectuals who succeeded the colonial administrators. Entrusted with stupefying the Muslim masses, they spread the socio-cultural and epistemic worldviews handed to them by their former masters, premised on the supremacy of Western civilisation. This westernised intelligentsia, which frequently comprises the state's cultural and economic elite, introduced an imported self-perception of mimicry that actually reflects slavish dependence and intended to replace the traditional Muslim selfawareness. It is clear that they have met with considerable success.

In cooperation with their military-political-business counterparts, they sought to implant a new national culture that harmonised with the western worldview. Economic achievement and the creation of a higher standard of living for the elites, both protected by the new state's political and military powers, were never meant for the masses. Consequently, the Muslim world now faces intellectual, military, and economic problems that have deep roots within its western-originated intelligentsia. Over the last several decades, the lack of an indigenous Muslim intelligentsia with its own supportive institutions, including public opinion and an independent information system, has caused a number of economic and political crises. ${ }^{32}$ The current global conditions indicate that these crises might provoke a new civilisational axis in the Muslim ummah if they are dealt with seriously and patiently with an eye to the long duration by combined networked efforts. 


\section{The Dilemma of a Just World System within Western Civilisation}

The slogan proposed by the western elites to bring peace, freedom, and liberty to other peoples now appears rather unpersuasive to non-Western peoples. Such calls for democracy, freedom, and human rights merely support or reinforce Western strategic interests..$^{33}$ In that respect, one must ask whether the ideological understanding of the international system can propose an ideal set of values that guarantee these mentioned values on Hegelian philosophic foundations or not. Before saying 'definitely not', the fundamental purpose of Fukuyama's reference to this philosophical system ${ }^{34}$ justifying his fanciful delusion of 'the end of history' was to conceal the modernist paradigm's crisis and failure to establish a just world system. This theory sought to present itself as the philosophical background for the New World Order $^{35}$ upon which the Western-centric civilisation rests. Davutoğlu has cogently emphasized that the original Hegelian understanding of the role of international law and recognised organisations would have been correct and surely more truthful than Fukuyama's view, if Hegel had had the opportunity to see the existing situation. "The practices of the collective security system as the most successful institutionalisation of international law proves that its analysis is not relevant for the development of a universal value system for the ethics of the international system. The clear-cut doublestandard of the United Nation's role in the Gulf war and during the Bosnian ${ }^{36}$ crisis demonstrated the fact that the only force in international politics is the particular wills of the great powers. ${ }^{{ }^{3} 7}$

This double standard was again displayed when Israel attacked the humanitarian activists' Gaza flotilla that had as its purpose delivering humanitarian supplies to impoverished Palestinians and trying to break the years-long Israeli siege. Nineteen people were killed in the deadly attack which occurred in international waters. The West sided with Israel. After Turkey's foreign minister acted, the UN Human Rights Council adopted a resolution setting up an independent international probe into the event; thirty-two countries condemned this "outrageous attack". Given the Euro-American states' resource-centred strategic international policy and very close relationship with Israel, they refused to condemn their ally's deadly attack. Moreover, Israel rejected calls from the UN and others for an international investigation. Such a clear double standard causes people to ask two questions:

1. How can such a power-centred international policy bring justice and freedom to oppressed and humiliated peoples? and

2. can the international system bring justice, freedom, and equal opportunity to all nations and peoples? Unfortunately, the answer to both questions is a resounding "No". 
The world needs a new system because the current one is unjust. The international system is a reflection of the oligarchic structure of the Cold-War era which accorded special missions to five permanent members of the Security council to decide and veto for the most essential issues of the international relations. If the structure is a fair formation, there would have been a tendency to a more democratic structure in international relations and, this tendency would have been started and guided by the United Nation and other democratic countries. The oligarchic structure of the western world-system has been transformed into a monopoly. Today, any decision of any significant international issues is subject to the strategic priorities of the Western elite. The special mission of the international organisations became justification of this decision. ${ }^{38}$ Israel's deadly attack on the flotilla is a clear evidence of its sense of justification.

Western civilisation's prejudice vis-à-vis Islam and the Muslims, both of which it proclaims are 'incompatible' with the globalised world system, grows out of its historical reality. Consider the following observations made by Davutoğlu:

First of all, Islamic civilisation was the only civilisation which had a superior past over western civilisation. In fact, one of the reasons behind western geographical searches for new trade routes in the $15^{\text {th }}$ and $16^{\text {th }}$ centuries was the Muslim supremacy in Eastern Europe and the Mediterranean. The other civilisations and authentic cultures, which have suffered because of western globalism today, did not have such supremacy in the past. So, Muslim nations were the frontal enemies in western history. Secondly, Muslim societies resisted the colonial expansions throughout the $19^{\text {th }}$ and $20^{\text {th }}$ centuries while many other societies easily accepted western supremacy. Thirdly, today, Muslim masses are trying to reproduce their own civilisational parameters and cultures in an age of globalism and monopolisation of culture. ${ }^{39}$

In addition to its existing socio-economic and democracy-related double standard, Western civilisation continues, without any apparent embarrassment, to work to impose its materialist human-centric system upon Asian countries while nevertheless encouraging certain types of religious identity. Tellingly, the majority of Americans today believe that their own country's laws should be based on religious, rather than secular, law. ${ }^{40}$

\section{A Rising Islamic Civilisation and Muslim Identity}

When the Muslim world's twentieth-century political history is analysed, one may easily observe that Islamic civilisation and cultural dynamism are both undergoing a serious renewal. ${ }^{41}$ The turn of the twentieth to the twenty-first century could be considered the era of Islamic civilisational reawakening. The situation of Iraq and Afghanistan-occupied for economic and strategic reasons - indicates that American 
plans have not turned out as expected. Even though they deployed the latest technological means and weapons, both wars have been lost. But in an attempt to save face they must camouflage this reality. One way to do this is to create an enemy, yet with the ongoing revival and reawakening of Muslim societies around the world, this explanation is no longer universally believed. The world's political atmosphere is acquiring a new face. Israel's position in the Middle East is deteriorating and causing serious concern among the Muslim states as it continues to embark upon illegal actions. Given that it is the only nuclear Middle Eastern state (and wants to remain so), controlling Iran in terms of its nuclear program has become a core element of Israel's overall security policy.

All of the resulting tensions indicate that a new global world system is needed, for the western-centric understanding of civilisation cannot be imposed on others. The mantra of human rights, democracy, and the right of ontological freedom must extend all such values for everyone. Iranian president Ahmadinejad's statement, "Nuclear weapon for no one, nuclear energy for everyone", ${ }^{42}$ made during his speech at the UN Security Council, attracted considerable interest around the world. In their pursuit of maintaining the status quo, the US asserts that all options "remain on the table"; yet it ignores any UN resolutions which conflict with its exceptionalist agenda. Muslim peoples are not represented on the UN Security Council, although they make up one-third of the world's population. True, the General Assembly gave Azerbaijan, Guatemala, Morocco, Pakistan and Togo the right to serve as non-permanent members of the Security Council for two-year terms starting 1 January 2012 (replacing BosniaHerzegovina, Brazil, Gabon, Lebanon and Nigeria). ${ }^{43}$ This small gesture carries no weight, and the veto wielded by the Security Council members remains a potent weapon - as we have just seen with Russia's cancelling the UN resolution condemning Syria. Along with many other nations, Muslim states believe that the United Nations was established to benefit all nations, not only those at the power centre.

All of these arrogant interests, negative attitudes, illegitimate attacks, illegal invasions, and arbitrary practices have caused the Muslim peoples to rethink their situation and work on restoring their identity. Turkey's recent diplomatic initiatives for world peace have received the support of many leaders and well-intentioned people who are hopeful of the emergence of a new world system, one that respects international law, human dignity, and ontological freedom for all. A significant gathering in Rio de Janeiro in 2010, the Third Forum of the United Nations Alliance of Civilisations, insisted that a dialogue among cultures will be the cornerstone for establishing a new global political order. This event brought together nearly 7,000 delegates from 100 countries. Its two co-sponsors, Turkey and Spain, reaffirmed their desire to open the paths of fairness, pluralism, and democracy.

Despite the well-established westernisation programs and its monopoly over technology, financial structures, media, and weapons, many revitalisation activities 
have appeared in colonised Muslim lands. Ideological resistance was waged in many places, intellectual and social ferment occurred within certain societies, and political movements and communities were structured so as to function as new alternative channels in the social realm. Many seminal Muslim thinker-activists appeared, including Khayr al-Dīn al-Tūnisī (1822-89), Sayyid Aḥmad Khān (1817-1898), Jamāl al-Dīn al-Afghani (1839-1897), ${ }^{44}$ Muḥammad 'Abduh (d. 1905), ${ }^{45}$ Rashīd Riḍā (1865-1935), Ahmad Hilmi (1865-1914), ${ }^{46}$ Sayyid Bey (1873-1924), Sayyid Amir Ali (d.1928), Muḥammad Iqbāl (1873-1938), ${ }^{47}$ Muhammad Hamdi Yazir (1878-1942), ${ }^{48}$ Mehmet Akif (1873-1936), Said Nursi (1876-1960), ${ }^{49}$ Ali Abdur Raziq (1888-1966), Ayatollah Khomeini (1902-1989), and M. Esad Coşan (1938-2001), who sacrificed their energy or lives to make the Muslims more conscious of the negative effects of Western political, intellectual, and military dominance and to arouse a more effective response. ${ }^{50}$ The dominant colonial European powers viewed these efforts and confrontations as hopeless struggles, the last fluttering of the Muslim masses, or the final gasp of Islamic civilisation. But they forgot one very significant reality: the ontological awareness of being Muslim and the dynamic energy of the Islamic spirit cannot be eliminated easily. Sincere devotion to God, the essence of Islam, encourages all Muslims to engage in these personal struggles. Accordingly, all such 'hopeless' activities and efforts served as compost for fertilising the psychological impetus for revitalising their strong self-perception and Islamic awareness. ${ }^{51}$

Fortunately after a half-century of pacification this intellectual and social awakening began to change the situation. All cultural, economic-political, and intellectual values were analysed and subjected, in varying degrees, to forms of Islamisation (often defined as the effort to restore a purer more authentic Islamic faith and practice). ${ }^{52}$ The Western colonial powers were not idle during this period. In an attempt to block this newly emerging reality, they imposed a new international order grounded upon the nation-state, seeking to preserve their imperialist advantage. Its apparatus eventually made Muslim countries economically, culturally, and politically dependant on western imperialism. But this new system did not work as efficiently as it was expected to, thanks to the dynamic structure and community-wide identity of the Muslim masses. "This irreconcilability created new dynamic tendencies in theory and practice and this encouraged Muslim groups and intellectuals to search for new conceptualisations and theoretical frameworks to replace the traditional background." ${ }_{53}$

In order to reconceptualise Islamic society and polity and to invigorate the Muslim mind, significant intellectuals sacrificed their energy. Sayyid Quṭb (19061966), Mawdūdī (1903-1979), Abdulkadir Udeh (1907-54), ${ }^{54}$ Fazlur Rahman (19191988), ${ }^{55}$ cAlī Sharī atî̀ (1933-1977), ${ }^{56}$ Heasan al-Turābī (b.1932), Rashīd al-Ghannūshī (b.1941), Hasan al-Bannā (1906-1949), and others throughout the Muslim world impelled the newly educated class of Muslims toward revival through their research, publications, and models of action. Their efforts toward political reform led to the 
establishment of Islamic political organisations such as the Arab League (in 1945) and the Organisation of Islamic Conference (in 1969; now renamed Organisation of Islamic Cooperation on 28 June 2011). ${ }^{57}$ Faced with such realities, the Westerncentric powers concealed their true intentions behind humanistic slogans of the UN's collective security system. Their prejudicial approaches remained clear, however, and only served to strengthen among all Muslims the desire to revitalise all of Islam's civilisational factors. We argue that a century and a half of European and now American confrontational and misguided policies have provoked Muslims to join forces in order to realise their historical, social, and political responsibilities to themselves and to humanity in general. One result of their newly emerging solidarity leading to wider strategic thinking among Muslim governments and individuals was the international condemnation of Israel's actions in Gaza (January 2009) and of the aid flotilla incident.

Economic strength leads to increased social unity as well as fortified cultural values. The power of money represents an individual's as well as a nation-state's economic power. On 10 June 2010, Turkey agreed to create a free trade zone without visa restrictions within Syria, Jordan, and Lebanon, an action it viewed as a strategic manoeuvre to counter Western financial agendas. In response the Western powers have sought to block and even forbid Turkey from 'collaborating' with its 'enemy', even though various European countries have been increasing their trade daily with this enemy. Turkey's relationships with its neighbours will strengthen its economic structure, thereby making it a strong regional player; by default, it may also be regarded as an opponent of the Western hegemonic interests. Indeed, Turkey's 'zeroproblems' policy ${ }^{58}$ with its neighbours has now strengthened its self-perception and energised its social, political, and economic spheres. Foreign Minister Davutoğlu's announcement that "we want a vehicle from Kars reaching to Morocco and Mauritania, from Sinop to Sudan and from Istanbul straight to the Gulf of Aden without stopping at any border gates" ${ }^{\prime 59}$ envisions a borderless economic, cultural, and political unity joining Turkey with the Arab World and North Africa. Furthermore his statement that "Israel's raid on a Gaza-bound aid flotilla was Turkey's September 11 ${ }^{\text {th" }}$ points to the stirrings of the new world system.

\section{Conclusion and Recommendations}

An alternative world system is desperately needed since the one now in place does not fulfil the demands of all newly awakened people: that humans in general, including non-white peoples in Asia and Africa, are entitled to enjoy the same level of equal educational and economic opportunity, security, and protection of human dignity as is said to be upheld in Europe and North America. However, their invoking these values remains no more than a rhetorical flourish designed to further achieve and maintain 
the strategic and financial interests of Western governments. They maintain that if all nations were to achieve real equal opportunities and benefit from technology transfers, Western civilisation and its Western-centric worldview would collapse.

The survival of a given civilisation does not depend only on material and financial strength. According to divine revealed law as expressed within Judaism, Christianity, and Islam, civilisational survival and flourishing is based on definite parameters: justice, moral virtues, human dignity, and freedom. If these are corrupted or obscured, God metes out retribution upon the civilisation by decadence and eventual collapse. History records the destruction and oblivion of many prosperous civilisations because of the injustice of leaders or elites, rebellious (anti-divine) activities, and corrupt selfish attitudes.

Many non-western peoples, especially Muslims, now realise that the materialist exceptional Euro-American civilisation cannot ensure universal democracy, equality, equity, and prosperity. This realisation pushes Muslim countries to actively collaborate with one another and begin deliberating more strategically. Many Muslim peoples are striving to revitalise their geo-cultural paradigms, evidenced by the ongoing 'Arab Awakening' unfolding before our eyes.

We should understand that Muslim civilisational reawakening may erase their long-standing inferiority complex toward the West, and abolish the long-held 'servant' mentality toward their former imperial masters. The increasing intensity of invigorated Muslim ontological awareness is already showing the effect of alarming the powers presently dominating our world system. The Western elites now fear that the Islamic world may regain its intensified self-awareness and ontological consciousness - and thereby move beyond the orbit of control. A new era is dawning - not the imagined 'end of history', but the end of Western-centric civilisation itself, and the emergence of a truly cosmopolitan world system. The twenty-first century will witness the emergence of freshly awakened civilisational blocs such as China and Islam that may prompt the reawakening of other oppressed civilisations and peoples for the sake of humanity as a whole and the wellbeing of our global reality.

The most relevant and pragmatic outcome and recommendations which we would emphasise resolves into the following:

- Muslim civic initiatives and the conscious efforts by Islamic nations must develop their intellectual and material resources for strengthening and expanding the global network of the leading Muslim scientific, educational, economic and cultural institutions in order to promote more effective cooperation, a combined pursuit of shared goals, and clarity of purpose and method.

- The expansion of this ummah-wide network will facilitate the recovery of Islamic ontological self-awareness, alleviate 'civilisational amnesia', and powerfully encourage rethinking and reclaiming the key universal values for realising the new world system where Islam plays a vital and leading role. 


\section{Notes}

1. For a cogent overview of Islam's attitude toward Nature and its response to environmental degradation, see Professor Mohammad Hashim Kamali, "Environmental Care in Islam: A Qur'anic Perspective," Islam and Civilisational Renewal 3, no. 2 (January 2012), 261-283.

2. Ahmet Davutoğlu, Civilisational Transformation and the Muslim World (Kuala Lumpur: Mahir Publication, 1994), 10.

3. Sezai Karakoç, Sütun, günlük yazılar (Istanbul: Diriliş Yayınları, 2010), 282.

4. Karen Barkey, "Islam and Toleration: Studying the Ottoman Imperial Model," International Journal of Politics, Culture, and Society 19, nos. 1-2, (2005), 15.

5. Niyazi Berkes (ed.), Turkish Nationalism and Western Civilisation (London: Hazell Watson and Viney, 1959), 77.

6. Davutoğlu, Civilisational Transformation, 53.

7. Shamsul A. B., "Colonial Knowledge and the Deepening of Orientalism: The Asian Experience," in: ed. Azizan Baharuddin (ed.), Occidentalism and Orientalism: Reflections of the East and the Perceptions of the West (Kuala Lumpur: University of Malaya Press, 2008), 4-9.

8. Ahmet Davutoğlu, Stratejik derinlik Türkiye'nin uluslararası konumи (Istanbul: Küre Yayınları, 2009), 248-250.

9. John O. Voll, Dialogue between Islam and the West: Where Are We Now and Where Are We Going? (Kuala Lumpur: Academe Art Printing Services, 2008), 9.

10. Muhammad Sahimi, "Double Standards for Iran's Nuclear Program," The Washington Report on Middle East Affairs 29, no. 3 (April 2010), 28. See also Iran Affairs, 17 June 2010, available online at http://www.iranaffairs.com/iran_affairs/2010/06/double-standards-for-irans-nuclear-program. html (accessed on 1 March 2012).

11. See http://www.worldbulletin.net/news_detail.php?id=59205, World Bulletin, 29 May 2010 (accessed on 1 March 2012).

12. Pepe Escobar, :The Roving Eye: Iran, Sun Tzu and the Dominatrix," Asia Times Online, 22 May 2010, available online at http://www.atimes.com/atimes/Middle_East/LE22Ak01.html (accessed on 1 March 2012).

13. Davutoğlu, Civilisational Transformation, 13-14. See also Bertrand Russell, History of Western Philosophy (London: Routledge, 2004), 556.

14. Brian Swann and Arnold Krupat, Recovering the Word: Essays on Native American Literature (Berkeley and Los Angeles: University of California Press, 1987), 525-30.

15. S. H. Nasr, Man and Nature: The Spiritual Crisis of Modern Man (Kuala Lumpur: Foundation for Traditional Studies, 1976), 94-95.

16. Pitirim A. Sorokin, "Arnold J. Toynbee's Philosophy of History," The Journal of Modern History 12, no. 3 (September 1940), 374-87. See also Ahmet Davutoğlu, Alternative Paradigms the Impact of Islamic and Western Weltanschauungs on Political Theory (New York: University Press of America, 1994) and idem, Civilisational Transformation, 26.

17. Davutoğlu, Civilisational Transformation, 26-27.

18. Ibid., 65 .

19. John O. Voll, İslam süreklilik ve değiş̧im, trans. Cemil Aydın (Istanbul: Yöneliş, 1995), 2:292.

20. Qur'ān 95:4.

21. Alija Ali Izetbegovic, Islam between East and West (Indianapolis IN: American Trust Publication, 1991), 39-40.

22. Davutoğlu, Civilisational Transformation, 65-68.

23. Ibid., 79 .

24. Ibid., 80 .

25. Qur'ān 91:14.

26. Ibid., 29:34.

27. Ibid., 7:96.

28. Malek Bennabi, Islam in History and Society (Kuala Lumpur: Berita, 1991), 10. 
29. Sezai Karakoç, Diriliş neslinin amentüsü (Istanbul: Diriliş Yayınları, 2007), 30-50.

30. Lee Poh Ping, "East-West Interaction and the Future Three Scenarios," in: Azizan, Occidentalism, 162.

31. Izetbegovic, Islam, 153.

32. Davutoğlu, Civilisational Transformation, 85-89.

33. Lee Poh Ping, "East-West Interaction," 158-160.

34. Francis Fukuyama, The End of History and the Last Man (New York: The Free Press, 1992), 199293; idem, “Are We at the End of Eistory?" Fortune Magazine 121, no. 2 (15 January 1990), 75-78; idem, "The End of History?" The National Interest 16 (Summer 1989), 3-18.

35. Davutoğlu, Civilisational Transformation, 99-100.

36. For a substantial perspective of the Bosnian crisis, see Aliya İzzetbegoviç, Tarihe tanıklığım (Istanbul: Klasik Publication, 2003).

37. Ibid., 100 .

38. Davutoğlu, Civilisational Transformation, 100.

39. Ibid., 103.

40. John L Esposito, American Muslims and the Future of American-Islamic World Relations (Kuala Lumpur: Academe Art and Printing Sevices, 2008), 7.

41. Davutoğlu, Civilisational Transformation, 105.

42. http://www.fpif.org/articles/abandoning_sabotage_in_iran (accessed on 1 March 2012).

43. http://www.un.org/sc/members.asp (accessed on 1 March 2012).

44. Hayreddin Karaman, Gerçek İslamda birlik, Afgani, Abduh, Reşit Rıza (Istanbul: Nesil Publication), 34; Majid Fakhri, Íslam felsefesi tarihi, trans. Kasım Turhan (Istanbul: 1992), 304; Jamal al-Din Afghani and Samarrai Hasib, Dini modernizmin üç şovalyesi (Istanbul: Bedir Publication, 1998).

45. Zeki İşcan, Muhammed 'Abduh'un dini ve siyasi görüşleri (Istanbul: Dergah, 1998), 149-67; Malcolm H. Kerr, Islamic Reform: The Political and Legal Theories of Muhammad 'Abduh and Rashid Rida (Berkeley and Los Angeles: University of California Press, 1966); W. Montgomery Watt, Islamic Fundamentalism and Modernity (London: Routledge, 1988), 51.

46. İsmail Kara, Türkiye'de islamcllı düşüncesi (Istanbul: Risale, 1986), 1:14.

47. Muhammad Iqbal, İslamda dini düşüncenin yeniden doğuşu, trans. N. Ahmad Asrar (Istanbul: Birleşik, n.d.), 19.

48. Mehmet Aydın, Elmalı'lıda teceddüd fikri, (Istanbul: Ufuk, 2000), 188.

49. Said Nursi, Sözler (Istanbul: Yeni Asya Publications, 1998), 442.

50. Saim Kayadibi, "Ijtihad and a Modernist Perspective towards Islamic Law and Thought," Journal of Islamic Law Studies 11 (2008), 126-29.

51. Davutoğlu, Civilisational Transformation, 105-109.

52. Chandra Muzaffar, "Islamization of State and Society: Some Further Critical Remarks," in: Norani Othman (ed.), Shari'a Law and the Modern Nation-State, (Kuala Lumpur: United Selangor Press, 1998), 113-122.

53. Davutoğlu, Civilisational Transformation, 109.

54. Abdulkadir Udeh, Sömürge hukuku ve İslam (Istanbul: İşaret, 1988).

55. Fazlur Rahman, Revival and Reform in Islam, ed. Ebrahim Moosa (Oxford: One World Publications, 2000), 47; idem, Islam and Modernity (Chicago: The University of Chicago, 1982).

56. Ali Shari’ati , Öze dönüss, trans. Kerim Güney (Istanbul: Kitabevi, 1999), 38-41.

57. http://en.wikipedia.org/wiki/Organisation_of_Islamic_Cooperation (accessed on 1 March 2012).

58. Ahmet Davutoğlu, “Turkey's Zero-Problems Foreign Policy," Foreign Policy (Washington DC: Slate Group, 2010), available online at http://www.foreignpolicy.com/articles/2010/05/20/turkeys_ zero_problems_foreign_policy?hidecomments=yes (accessed on 1 March 2012).

59. "Turkey to Create Regional Free-Trade, Tourism Region," Today's Zaman, available online at http:// www.todayszaman.com/newsDetail_getNewsById.action?load=detay\&link=212687 (accessed on 1 March 2012). 